\title{
STRATEGI PENGEMBANGAN UMKM MEUBEL DI KOTA BENGKULU
}

\author{
Agusman Ardin ${ }^{1}$, Rahmat Al Hidayat ${ }^{2}$ \\ ${ }^{1}$ Dinas Koperasi dan UKM Kota Bengkulu, ${ }^{2}$ Sekolah Tinggi Ilmu Administrasi Bengkulu \\ Email: komaeshinogawa@yahoo.com ; yynrahmad@gmail.com
}

\begin{abstract}
ABSTRAK
Penelitian ini bertujuan untuk mengidentifikasi faktor-faktor internal dan eksternal yang dihadapi UMKM meubel di Kota Bengkulu, menentukan strategi pengembangan UMKM meubel di Kota Bengkulu. Data yang digunakan dalam penelitian ini adalah data primer yang diperoleh dari pelaku UMKM meubel di Kota Bengkulu pada tahun 2015 dengan menggunakan alat analisis SWOT. Hasil analisis dengan SWOT dapat disimpulkan bahwa faktor internal dalam strategi pengembangan yang digunakan oleh UMKM meubel di Kota Bengkulu adalah; 1) Faktor Kekuatan (produk bernilai ekonomis tinggi, kualitas produk, sistem kekeluargaan, menjalin kerjasama dengan pemerintah); 2) Faktor kelemahan (teknologi, ketersediaan SDM, kapasitas produksi, modal usaha, promosi produk), untuk faktor eksternal dalam strategi pengembangan yang digunakan oleh UMKM meubel di Kota Bengkulu adalah; 1) Faktor peluang (peningkatan income per kapita, dukungan pemerintah, jumlah penduduk, upah tenaga kerja, stabilitas politik); 2) Faktor ancaman (ketersediaan bahan baku, harga bahan baku, daya beli masyarakat, produk sejenis, tarif dasar listrik dan bahan bakar). Strategi yang harus diterapkan dalam kondisi ini adalah strategi SO (Strenghts-Opportunies), yaitu; 1) Memperluas pangsa pasar; 2) Mempertahankan dan meningkatkan kualitas layanan kepada pelanggan; 3) Meningkatkan kualitas produk.
\end{abstract}

Kata Kunci: Strategi, Kekuatan, Kelemahan, Peluang, dan Ancaman.

\begin{abstract}
This study aims to identify internal and external factors faced by furniture MSMEs in Bengkulu City, determine the strategy for furniture MSME development in Bengkulu City. The data used in this study are primary data obtained from furniture UMKM actors in Bengkulu City in 2015 using a SWOT analysis tool. The results of the SWOT analysis can be concluded that internal factors in the development strategy used by the UMKM furniture in Bengkulu City are; 1) Strength factor (high economic value products, product quality, family system, collaborating with the government); 2) Weaknesses (technology, availability of human resources, production capacity, business capital, product promotion), for external factors in the development strategy used by the UMKM furniture in Bengkulu City are; 1) Opportunity factors (increasing per capita income, government support, population, labor costs, political stability); 2) Threat factors (availability of raw materials, price of raw materials, public purchasing power, similar products, basic electricity and fuel tariffs). The strategy that must be applied in this condition is the SO (Strengths-Opportunies) strategy, namely; 1) Expanding market share; 2) Maintaining and improving the quality of service to customers; 3) Improve product quality.
\end{abstract}

Key Words: Strategy, Strengths, Weaknesses, Opportunities and Threats. 


\section{PENDAHULUAN}

Pengangguran di Indonesia masih menjadi persoalan pelik.BPS (2012)mencatat peningkatan angka pengangguran di Indonesia.Jumlah penduduk yang bekerja di Indonesia pada Agustus2012 mencapai 110,8 juta orang, berkurang sekitar 2,0 juta orang dibanding keadaan pada Februari 2012 sebesar 112,8 juta orang atau bertambah 1,1 juta orang dibanding keadaan Agustus 2011.Sektor informal adalah sektor yang mengalami penurunan tingkat pengangguran.Sektor-sektor tersebut adalah sektor pertanian sebesar 450 ribu orang (1,14 persen), sektor perdagangan sebesar 250 ribu orang (1,07 persen), dan sektor transportasi, pergudangan, dan komunikasisebesar 80 ribu orang (1,57 persen).

Gambaran tersebut menunjukkan bahwa pengangguran menjadi masalah yang krusial bagi Indonesia. Meningkatnya angka pertumbuhan ekonomi tidak dengan serta merta mengurangi tingkat pengangguran. Selain itu, harus diakui bahwa gambaran perekonomian Indonesia kedepan dalam waktu singkat masih tampak suram. Investasi skala besar, yang pada masa sebelum krisis menjadi salah satu andalan pertumbuhan dan penyerapan tenaga kerja, masih sulit diharapkan. Dengan kondisi semacam itu, tidaklah mengherankan jika banyak pihak kemudian beralih pada pengembangan Usaha Menengah Kecil Menengah (UMKM). Bagi para pendukung usaha kecil, baik praktisi maupun akademisi, kondisi sekarang dilihat sebagai saat pembuktian bahwa perekonomian berbasis UMKM lebih baik karena usaha ini terbukti mempunyai daya tahan yang tinggi terhadap krisis, lebih banyak menyerap tenaga kerja, dan lebih bisa memberikan kesejahteraan bagi rakyat kecil.

Pengembangan UMKM merupakan sarana yang tepat dalam rangka pemberdayaan masyarakat. Hal ini ditandai dengan sifat dan bentuk UMKM (Bantacut dkk, 2001) yaitu :

1. Berbasis pada sumberdaya lokal sehingga dapat memanfaatkan potensi secara maksimal dan memperkuat kemandirian,

2. Dimiliki dan dilaksanakan oleh masyarakat lokal sehingga mampu mengembangkan sumber daya manusia,

3. Menerapkan tekhnologi lokal sehingga dapat dilaksanakan dan dikembangkan oleh tenaga lokal,

4. Tersebar dalam jumlah yang banyak sehingga merupakan alat pemerataan pembangunan yang efektif Pemerintah menyusun rencana dan kebijakan pengembangan iklim usaha yang kondusif serta peningkatan daya saing UMKM. Hal ini dilakukan untuk memecahkan masalah-masalah tersebut di atas. Beberapa arah kebijakan pembangunan pemberdayaan koperasi dan UMKM (Depkop, 2014) adalah:

1. Meningkatkan iklim usaha yang kondusif bagi koperasi dan UMKM, yang mencakup penataan peraturan perundang-undangan di bidang koperasi dan UMKM, serta pengembangan, pengendalian dan pengawasan koperasi.

2. Mengembangkan produk dan pemasaran bagi koperasi dan UMKM, yang mencakup penyediaan dukungan pemasaran, produksi, kemitraan, investasi dan pengembangan produk unggulan. 
3. Meningkatkan daya saing sumber daya manusia (SDM) koperasi dan UMKM, yang mencakup pemasyarakatan dan pengembangan kewirausahaan, kapasitas dan kompetendi SDM, penyediaan layanan pengembangan bisnis, revitalisasi dan pelatihan koperasi dan UMKM, serta peningkatan peran serta masyarakat dalam pengembangan SDM koperasi dan UMKM.

4. Meningkatkan akses usaha mikro dan kecil kepada sumberdaya produktif, yang meliputi peningkatan akses permodalan, pengembangan dan pengendalian koperasi simpan pinjam yang disertai dengan peningkatan kapasitas dan kompetensi pengelilannya, pengembangan jasa keuangan bagi koperasi dan UMKM, perluasan KUR, dan

5. Memperkuat kelembagaan koperasi, yang mencakup peningkatan kualitas organisasi dan badan hukum koperasi, ketatalaksanaan koperasi, dan keanggotaan koperasi, serta penguatan kapasitas koperasi sesuai dengan amanat Undang-Undang No. 17 tahun 2012 tentang perkoperasian.

Tujuan pengembangan UMKM (usaha mikro, kecil dan menengah) baik yang dilakukan di Indonesia adalah bertujuan untuk meningkatkan kesejahteraan masyarakat atau mengurangi tingkat kemiskinan. UMKM di Kota Bengkulu juga telah sejak lama dianggap atau diharapkan menjadi salah satu sektor yang akan memainkan peranan penting dalam pembangunan ekonomi daerah. Tabel 1 menunjukkan jumlah UMKM yang ada di Kota Bengkulu.

Data pada Tabel 1 menunjukkan bahwa pada tahun 2009 jumlah UMKM sebesar 2.958 dengan 3.889 tenaga kerja. Pada tahun 2010 terjadi peningkatan jumlah UMKM sekitar 3.899 dengan jumlah tenaga kerja 9.927. Pada tahun 2011 terjadi penurunan dengan jumlah UMKM sekitar 3.469 dengan 7.953 tenaga kerja. Sedangkan pada tahun 2012 jumlah UMKM mengalami penurunan yg signifikan sekitar 1.012 dengan 2.169 tenaga kerja, dan pada tahun 2013 jumlah UMKM terdapat 2.146 dengan 5.051 tenaga kerja.

Jenis UMKM yang ada di Kota Bengkulu adalah perdagangan, industri, dan aneka jasa. Banyak usahausaha UMKM tumbuh dan berkembang di Kota Bengkulu, salah satu UMKM yang berkembang adalah usaha meubel. Pada Tabel 1 menjelaskan jumlah UMKM meubel di Kota Bengkulu

Tabel 1.Jumlah UMKM Meubel di Kota Bengkulu

\begin{tabular}{|l|c|}
\hline \multicolumn{1}{|c|}{ Kecamatan } & Jumlah \\
\hline Singaran Pati & 11 \\
\hline Gading Cempaka & 1 \\
\hline Selebar & 14 \\
\hline Kampung Melayu & 4 \\
\hline Muara Bangkahulu & 7 \\
\hline Ratu agung & 6 \\
\hline Ratu Samban & 8 \\
\hline Sungai Serut & 6 \\
\hline Teluk Segara & 2 \\
\hline Jumlah & 59 \\
\hline
\end{tabular}

Sumber: Dinas Koperasi dan PPKM Kota Bengkulu (2013) 
Tabel 1 menunjukkan seberapa banyak UMKM yang bergerak di bidang meubel, yaitu berjumlah 59 usaha di Kota Bengkulu. Banyak faktor yang menyebabkan berkembangnya UMKM meubel di Kota Bengkulu, diantaranya produk yang dihasilkan akan memiliki nilai ekonomis tinggi, dan adanya kerjasama dengan pemerintah dalam usaha peningkatan sektor perekonomian.

Perkembangan UMKM meubel di Kota Bengkulu memang cukup menjanjikan. Tetapi kemajuan UMKM meubel di Kota Bengkulu masih terasa berjalan di tempat, kualitas dan kuantitas produksi yang masih terbatas, dan penguasaan teknologi belum mumpuni menjadi salah satu penyebab perkembangan UMKM meubel di Kota Bengkulu masih tersendat. Untuk menghadapi keterbatasan tersebut dibutuhkan perumusan strategi yang tepat sebagai prioritas utama untuk pengembangan UMKM Meubel di Kota Bengkulu ke depan. Dari ulasan di atas, penulis tertarik untuk meneliti tentang "Strategi Pengembangan UMKM Meubel di Kota Bengkulu".

\section{TINJAUAN LITERATUR}

\section{Usaha Mikro Kecil dan Menengah}

Pengertian UMKM sesuai dengan Undang-Undang Nomor 20 Tahun 2008 tentang Usaha Mikro, Kecil dan Menengah (UMKM):

a. Usaha mikro adalah usaha produktif milik orang perorang dan/ atau badan usaha perorangan yang memenuhi kriteria usaha mikro sebagaimana diatur dalam Undang-Undang ini.

b. Usaha kecil adalah usaha ekonomi produktif yang berdiri sendiri, yang dilakukan oleh orang perorang atau badan usaha yang bukan merupakan anak perusahaan atau bukan cabang perusahaan yang dimiliki, dikuasai, atau menjadi bagian baik langsung dari usaha menengah atau usaha besar yang memenuhi kriteria usaha kecil sebagaimana dimaksud Undang-Undang ini.

c. Usaha menegah adalah usaha ekonomi produktif yang berdiri sendiri, yang dilakukan oleh orang perseorang atau badan usaha yang bukan merupakan anak perusahaan atau cabang perusahaan yang dimiliki, dikuasai, atau menjadi bagian baik langsung maupun tidak langsung dengan usaha kecil atau usaha besar dengan jumlah kekeyaan bersih atau hasil penjualan tahunan sebagaimana diatur dalam Undang-Undang ini

\section{Manajemen Strategi}

Manajemen strategi merupakan istilah yang banyak digunakan untuk menggambarkan proses keputusan yang merupakan fokus pembahasan ini. Menurut Umar (2008), manajemen strategis adalah seni dan ilmu untuk pembuatan (formulating), penerapan (implementing) dan evaluasi (evaluating) keputusankeputusan antarfungsi yang memungkinkan sebuah organisasi mencapai di masa yang akan datang. Perencanaan strategis lebih terfokus pada bagaimana manajemen puncak menentukan visi, misi, falsafah dan strategi perusahaan untuk mencapai tujuan perusahaan dalam jangka panjang. 
David (2004) mendefinisikan manajemen strategis merupakan ilmu tentang perumusan dan evaluasi keputusan-keputusan lintas fungsi yang memungkinkan organisasi mencapai tujuannya.Menajemen strategis terfokus pada upaya memadukan menajemen pemasaran, keuangan/akuntansi, peoduksi penelitian dan pengembangan, dan sistem informasi untuk mencapai keberhasilan dalam organisasi.Tujuan manajemen strategis adalah memanfaatkan dan menciptakan peluang-peluang baru dan berbeda di masa mendatang.

\section{Tahapan Penyusunan Strategi}

Lingkungan bisnis dapat dibagi menjadi dua, yaitu : lingkungan eksternal dan lingkungan internal.

a. Analisis lingkungan eksternal

Umar (2008) menjelaskan, lingkungan ekternal merupakan suatu proses yang dilakukan oleh perencanaan strategi untuk memantau sektor lingkungan dalam menentukan peluang dan ancaman bagi perusahaan.Kekuatan ekternal dapat dibagi menjadi dua yaitu: lingkungan makro dan lingkungan industri.

b. Analisis lingkungan internal

Lingkungan internal merupakan suatu kondisi yang ada di dalam suatu perusahaan. Analisis internal adalah proses perencanaan strategi menentukan letak kekuatan dan kelemahan suatu perusahaan. Lingkungan internal menurut David (2004) merupakan kekuatan dan kelemahan perusahaan pada area fungsional bisnis, termasuk manajemen, pemasaran, keuangan/akuntansi, produksi/operasi, penelitian dan pengembangan, dan sistem informasi manajemen

\section{Matriks Evaluasi Faktor Internal dan Eksternal (IFE-EFE)}

Sebelum membuat matriks faktor strategi internal dan eksternal, harus menentukan faktor strategi internal dan eksternal dengan langkah-langkah berikut (Kinnear dan Taylor, 1995):

a. Menyusun daftar faktor utama yang mempunyai dampak penting (critical success factors) untuk aspek internal (kekuatan dan kelemahan) dan aspek eksternal (peluang dan ancaman) yang ditempatkan pada kolom pertama.

b. Penentuan bobot dilakukan dengan mengajukan identifikasi faktor internal dan eksternal tersebut pada pihak manajemen dengan menggunakan metode "Paired Comparison".

c. Menentukan rating masing-masing faktor dengan skala 1 sampai 4 . Untuk matriks IFE, rating $1=$ sangat lemah, 2=lemah, 3=kuat, 4=sangat kuat. Dan matriks EFE, rating 1=dibawah rata-rata, 2=rata-rata, $3=$ diatas rata-rata, $4=$ sangat bagus.

d. Mengalikan nilai bobot dengan nilai rating untuk mendapatkan skor terbobot.

e. Menjumlahkan semua skor pembobotan secara vertikal untuk mendapatkan skor total bagi perusahaan yang dinilai. Pada matriks IFE total skor berkisar antara 1,0 s/d 4,0 dengan rata-rata 2,5 yang menunjukkan seberapa baik perusahaan merespon faktor-faktor strategis internal perusahaan sekarang dan yang diharapkan. Sedangkan matriks IFE, total skor matriks EFE juga berkisar antara 1,0 s/d 4,0 dengan rata-rata 2,5 yang menunjukkan seberapa baik perusahaan menanggapi faktor dalam lingkungan 
eksternalnya. Skor terbobot total merupakan hasil akhir yang didapat dari kedua matriks tersebut yang disajikan pada tabel 3 dan 4 .

Tabel 3. Matriks IFE

\begin{tabular}{|l|c|c|c|}
\hline \multicolumn{1}{|c|}{ Faktor Strategi Internal } & Bobot & Rating & Skor \\
\hline Kekuatan: & & & \\
\hline Kelemahan: & & & \\
\hline
\end{tabular}

Sumber: David, 2004

Tabel 4. Matriks EFE

\begin{tabular}{|l|c|c|c|}
\hline \multicolumn{1}{|c|}{ Faktor Strategi Eksternal } & Bobot & Rating & Skor \\
\hline Peluang: & & & \\
\hline Ancaman: & & & \\
\hline
\end{tabular}

\section{METODE PENELITIAN}

Sumber : David, 2004

Penelitian ini menggunakan metode penelitian deskriptif kualitatif, di mana dimaksudkan untuk menggambarkan lingkungan eksternal dan internal UMKM meubel di Kota Bengkulu. Metode penelitian kualitatif digunakan dalam suatu penelitian untuk memperolah gambaran secara kualitatif dan akan lebih banyak didominasi oleh kata- kata, kalimat maupun uraian serta jarang menggunakan data- data angka meskipun tidak menutup kemungkinan ditampilkannya tabel atau grafik untuk mendukung kelengkapan data. Jumlah UMKM meubel di Kota Bengkulu adalah 59 UMKM, dan tersebar di beberapa daerah di Kota Bengkulu.

. Pengambilan sampel digunakan rumus Sevilla (2000), dengan cara sebagai berikut :

dimana:

$$
\mathrm{n}=\frac{\mathrm{N}}{1+\left(\mathrm{N}\left(\mathrm{d}^{2}\right)\right)}
$$

$\mathrm{n} \quad=$ ukuran sampel

$\mathrm{N}=$ jumlah populasi

d2 = batas ketelitian, dipilih $13,5 \%$

Setelah menggunakan rumus Sevilla (2000) untuk menentukan jumlah responden, didapatlah 28 responden untuk diteliti.

Tabel 6.Jumlah Responden per Kecamatan

\begin{tabular}{|l|c|c|}
\hline \multicolumn{1}{|c|}{ Kecamatan } & UMKM & Responden \\
\hline Singaran Pati & 11 & 6 \\
\hline Gading Cempaka & 1 & 1 \\
\hline Selebar & 14 & 6 \\
\hline Kampung Melayu & 4 & 2 \\
\hline Muara Bangkahulu & 7 & 3 \\
\hline Ratu agung & 6 & 3 \\
\hline Ratu Samban & 8 & 3 \\
\hline Sungai Serut & 6 & 3 \\
\hline Teluk Segara & 2 & 1 \\
\hline Jumlah & 59 & 28 \\
\hline
\end{tabular}

Sumber: Data Diolah (2015) 


\section{Teknik Analisis Data}

Sebelum membuat matriks faktor strategi internal dan eksternal, harus menentukan faktor strategi internal dan eksternal dengan langkah-langkah berikut (Kinnear dan Taylor, 1995):

a. Menyusun daftar faktor utama yang mempunyai dampak penting (critical success factors) untuk aspek internal (kekuatan dan kelemahan) dan aspek eksternal (peluang dan ancaman) yang ditempatkan pada kolom pertama.

b. Penentuan bobot dilakukan dengan mengajukan identifikasi faktor internal dan eksternal tersebut pada pihak manajemen dengan menggunakan metode "Paired Comparison".

c. Menentukan rating masing-masing faktor dengan skala 1 sampai 4 . Untuk matriks IFE, rating $1=$ sangat lemah, 2=lemah, 3=kuat, 4=sangat kuat. Dan matriks EFE, rating 1=dibawah rata-rata, 2=rata-rata, $3=$ diatas rata-rata, $4=$ sangat bagus.

d. Mengalikan nilai bobot dengan nilai rating untuk mendapatkan skor terbobot.

e. Menjumlahkan semua skor pembobotan secara vertikal untuk mendapatkan skor total bagi perusahaan yang dinilai. Pada matriks IFE total skor berkisar antara 1,0 s/d 4,0 dengan rata-rata 2,5 yang menunjukkan seberapa baik perusahaan merespon faktor-faktor strategis internal perusahaan sekarang dan yang diharapkan. Sedangkan matriks IFE, total skor matriks EFE juga berkisar antara 1,0 s/d 4,0 dengan rata-rata 2,5 yang menunjukkan seberapa baik perusahaan menanggapi faktor dalam lingkungan eksternalnya. Skor terbobot total merupakan hasil akhir yang didapat dari kedua matriks tersebut yang disajikan pada tabel 7 dan 8 .

Tabel 7. Matriks IFE

\begin{tabular}{|l|c|c|c|}
\hline \multicolumn{1}{|c|}{ Faktor Strategi Internal } & Bobot & Rating & Skor \\
\hline Kekuatan: & & & \\
\hline Kelemahan: & & & \\
\hline
\end{tabular}

Sumber: David, 2004

Tabel 8. Matriks EFE

\begin{tabular}{|l|l|l|l|}
\hline \multicolumn{1}{|c|}{ Faktor Strategi Eksternal } & Bobot & Rating & Skor \\
\hline Peluang : & & & \\
\hline Ancaman : & & & \\
\hline
\end{tabular}

Sumber : David, 2004

Setelah mengumpulkan semua informasi dan melakukan analisis terhadap kondisi internal dan eksternal, selanjutnya adalah mengembangkan alternatif strategi. Perumusan strategi dapat dilakukan dengan menggunakan alat bantu matriks SWOT. Matriks ini dapat menggambarkan secara jelas peluang dan ancaman eksternal yang dihadapi lalu disesuaikan dengan kekuatan dan kelemahan yang ada. Adapun diagram yang menggambarkan analisis SWOT adalah sebagai berikut (Rangkuti, 2006): 


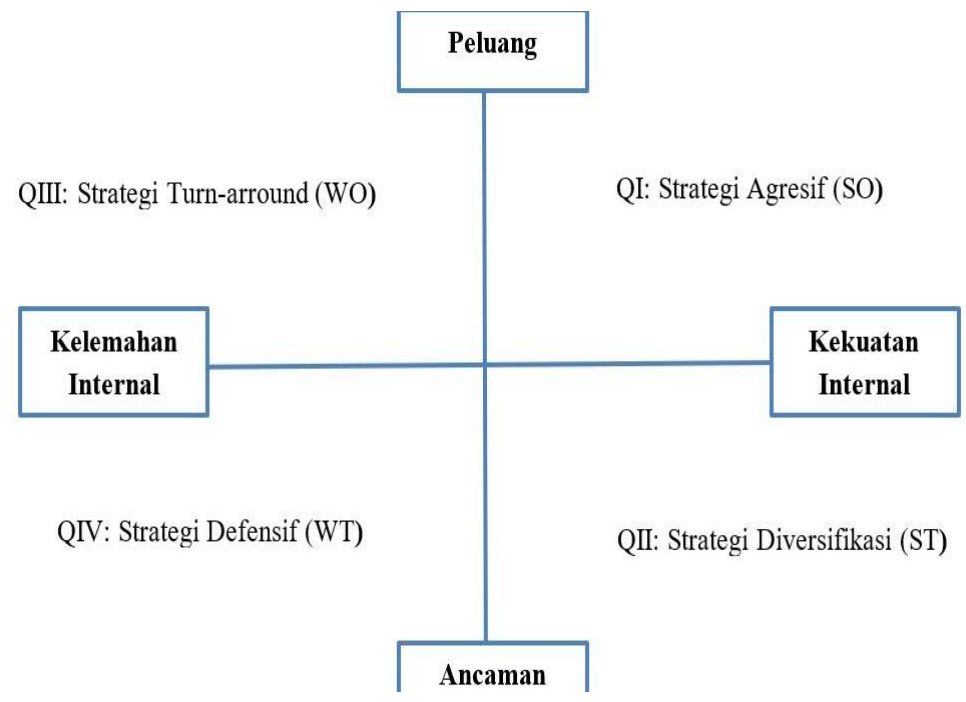

\section{Keterangan:}

\section{Kuadran 1 (positif, positif)}

Posisi ini menandakan sebuah organisasi yang kuat dan berpeluang, rekomendasi strategi yang diberikan adalah agresif, artinya organisasi dalam kondisi prima dan mantap sehingga sangat dimungkinkan untuk terus melakukan ekspansi, memperbesar pertumbuhan dan meraih kemajuan secara maksimal.

\section{Kuadran II (positif, negatif)}

Posisi ini menandakan sebuah organisasi yang kuat namun menghadapi tantangan yang besar. Rekomendasi strategi yang diberikan adalah Diversifikasi Strategi, artinya organisasi dalam kondisi mantap namun menghadapi sejumlah tantangan berat sehingga diperkirakan roda organisasi akan mengalami kesulitan untuk terus berputar bila hanya bertumpu pada strategi sebelumnya, oleh karena, organisasi disarankan untuk segera memperbanyak ragam strategi taktisnya.

\section{Kuadran III (negatif, positif)}

Posisi ini menandakan sebuah organisasi yang lemah dan menghadapi tantangan besar.Rekomendasi strategi yang diberikan adalah ubah strateginya, artinya organisasi disarankan untuk mengubah strategi sebelumnya.Sebab, strategi yang lama dikhawatirkan sulit untuk dapat menangkap peluang yang ada sekaligus memperbaiki kinerja organisasi.

\section{Kuadran IV (negatif, negatif)}

Posisi ini sebuah organisasi yang lemah dan menghadapi tantangan besar.Rekomendasi strategi yang diberikan adalah strategi bertahan, artinya kondisi internal organisasi berada pada pilihan dilematis.Oleh karenanya organisasi disarankan untuk menggunakan strategi bertahan, mengendalikan kinerja internal agar tidak semakin terperosok.Strategi ini dipertahankan sambil berupaya membenahi diri.

Teknik analisa data yang digunakan dalam penelitian ini adalah analisis deskriptif, dengan menggunakan Analisis SWOT, yakni suatu metode yang mengalisis faktor-faktor yang dimiliki oleh organisasi berupa: kekuatan, kelemahan, peluang, dan tantangan atau ancaman. 


\section{HASIL}

1. Faktor strategis internal (kekuatan dan kelemahan)

Tabel 9.Hasil Penilaian Faktor Internal

\begin{tabular}{|c|c|c|c|c|c|}
\hline No & Faktor internal & Bobot & Rating & $\begin{array}{l}\text { Nilai tertimbang } \\
\text { (bobot x rating) }\end{array}$ & $\begin{array}{l}\text { Keadaan UMKM meubel di } \\
\text { Kota Bengkulu sekarang }\end{array}$ \\
\hline & Kekuatan & & & & \\
\hline 1 & $\begin{array}{lr}\text { Memiliki } & \text { produk } \\
\text { yang } & \text { bernilai } \\
\text { ekonomis, } & \text { dan } \\
\text { berdaya } & \text { saing } \\
\text { tinggi } & \\
\end{array}$ & 0,11 & 4 & 0,45 & $\begin{array}{l}\text { Dengan peralatan } \\
\text { sederhana tetapi tetap } \\
\text { mengutamakan kualitas } \\
\text { yang dihasilkan }\end{array}$ \\
\hline 2 & $\begin{array}{ll}\text { Kualitas } & \text { produk } \\
\text { sesuai } & \text { dengan } \\
\text { pesanan } & \end{array}$ & 0,12 & 4 & 0,47 & $\begin{array}{l}\text { Mengutamakan mutu } \\
\text { atas permintaan } \\
\text { konsumen/pasar }\end{array}$ \\
\hline 3 & $\begin{array}{l}\text { Dikerjakan secara } \\
\text { kekeluargaan }\end{array}$ & 0,10 & 3 & 0,31 & $\begin{array}{lr}\text { Dapat } & \text { menekan } \\
\text { biaya/cost } & \text { yang } \\
\text { dikeluarkan } & \text { terutama } \\
\text { pada tenaga kerja }\end{array}$ \\
\hline 4 & $\begin{array}{l}\text { Terjalin kerjasama } \\
\text { yang baik dengan } \\
\text { pemerintah dalam } \\
\text { usaha peningkatan } \\
\text { sektor } \\
\text { perekonomian }\end{array}$ & 0,12 & 3 & 0,35 & $\begin{array}{l}\text { Perlu perhatiandan } \\
\text { pembinaan dari } \\
\text { pemerintah/instansi } \\
\text { terkait terutama SDM } \\
\text { dan berupa bantuan } \\
\text { modal usaha }\end{array}$ \\
\hline 5 & $\begin{array}{l}\text { Lokasi usaha yang } \\
\text { strategis dan } \\
\text { aksesbilitas yang } \\
\text { tinggi sehingga } \\
\text { terjangkau oleh } \\
\text { konsumen }\end{array}$ & 0,09 & 2 & 0,19 & $\begin{array}{l}\text { Terletak dipinggir jalan } \\
\text { raya dan mempunyai } \\
\text { gudang/toko di sekitar } \\
\text { pasar }\end{array}$ \\
\hline & & & & & \\
\hline & Kelemahan & & & & \\
\hline 1 & $\begin{array}{l}\text { Posisi umkm yang } \\
\text { masih melakukan } \\
\text { kegiatan secara } \\
\text { mandiri dengan } \\
\text { peralatan } \\
\text { sederhana }\end{array}$ & 0,09 & -3 & $-0,28$ & 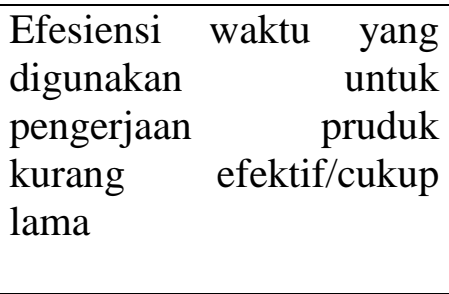 \\
\hline 2 & $\begin{array}{l}\text { Tenaga kerja, etos } \\
\text { kerja dan } \\
\text { produktivitas } \\
\text { masih kurang }\end{array}$ & 0,07 & -2 & $-0,14$ & $\begin{array}{l}\text { Peralatan masih manual } \\
\text { dan etos kerja } \\
\text { berkembang sendirinya } \\
\text { hanya berdasarkan } \\
\text { metode dan cara sendiri }\end{array}$ \\
\hline 3 & $\begin{array}{l}\text { Kapasitas produk } \\
\text { rendah }\end{array}$ & 0,07 & -2 & $-0,15$ & $\begin{array}{l}\text { Terbatasnya lokasi usaha } \\
\text { dan peralatan yang } \\
\text { digunakan }\end{array}$ \\
\hline 4 & Modal kerja yang & 0,12 & -4 & $-0,47$ & Skill dan nilai seni \\
\hline
\end{tabular}




\begin{tabular}{|c|l|l|l|l|l|}
\hline & terbatas & & & & $\begin{array}{l}\text { terhadap hasil pruduk } \\
\text { masih kurang }\end{array}$ \\
\hline 5 & $\begin{array}{l}\text { Kurangnya } \\
\text { promosi produk }\end{array}$ & & & & $\begin{array}{l}\text { Peranan } \\
\text { pemerintah/instansi } \\
\text { terkait masi kurang, } \\
\text { baik pembinaan, bantuan } \\
\text { serta keterlibatan pada } \\
\text { saat pameran/expo } \\
\text { sebagai kategori pruduk } \\
\text { unggulan }\end{array}$ \\
\hline & 0,10 & -3 & $-0,31$ & \\
\hline
\end{tabular}

Sumber: Hasil Penelitian (2015)

Pada Tabel di atas dapat dilihat bahwa jumlah skor faktor strategis internal (kekuatan dan kelemahan) untuk UMKM meubel di Kota Bengkulu adalah sebesar 0,41.Pada Tabel 9 di atas juga diperoleh kekuatan dalam Strategi Pengembangan UMKM Meubel di Kota Bengkulu adalah sebagai berikut:

a. Kualitas produk sesuai dengan pesanan $(0,47)$

b. Memiliki produk yang bernilai ekonomis, dan berdaya saing tinggi $(0,45)$

c. Terjalin kerjasama yang baik dengan pemerintah dalam usaha peningkatan sektor perekonomian $(0,35)$

d. Dikerjakan secara kekeluargaan $(0,31)$

e. Lokasi usaha yang strategis dan aksesbilitas yang tinggi sehingga terjangkau oleh konsumen $(0,19)$

Sedangkan kelemahan dalam Strategi Pengembangan UMKM Meubel di Kota Bengkulu adalah sebagai berikut:

a. Modal kerja yang terbatas $(-0,47)$

b. Kurangnya promosi produk $(-0,31)$

c. Posisi umkm yang masih melakukan kegiatan secara mandiri dengan peralatan sederhana $(-0,28)$

d. Kapasitas produk rendah $(-0,15)$

e. Tenaga kerja, etos kerja dan produktivitas masih kurang $(-0,14)$

\section{Faktor strategis eksternal (peluang dan ancaman)}

Tabel berikut merupakan hasil pengolahan faktor strategi eksternal, yaitu faktor peluang dan faktor ancaman dari UMKM meubel di Kota Bengkulu. Adapun dari 28 sampel yang diteliti menunjuukan hasil sebagai berikut:

Tabel 10.Hasil Penilaian Faktor Eksternal

\begin{tabular}{|c|c|c|c|c|c|}
\hline No & Faktor eksternal & Bobot & Rating & $\begin{array}{c}\text { Nilai } \\
\text { tertimbang } \\
\text { (bobot } x \text { rating) }\end{array}$ & $\begin{array}{l}\text { Keadaan UMKM } \\
\text { meubel di Kota } \\
\text { Bengkulu sekarang }\end{array}$ \\
\hline \multicolumn{6}{|c|}{ Peluang } \\
\hline 1 & $\begin{array}{l}\text { Meningkatnya } \\
\text { income per kapita }\end{array}$ & 0,12 & 4 & 0,47 & $\begin{array}{l}\text { Meningkatkan kualitas } \\
\text { pruduk meubel } \\
\text { terhadap persaingan } \\
\text { permintaan pasar dan } \\
\text { menggalakan }\end{array}$ \\
\hline
\end{tabular}




\begin{tabular}{|c|c|c|c|c|c|}
\hline & & & & & $\begin{array}{lr}\text { penggunaan } & \text { serta } \\
\text { cinta produksi dalam } \\
\text { negeri }\end{array}$ \\
\hline 2 & $\begin{array}{l}\text { Adanya dukungan } \\
\text { pemerintah dalam } \\
\text { mengembangkan } \\
\text { umkm }\end{array}$ & 0,12 & 4 & 0,49 & $\begin{array}{l}\text { Diikutsertakan pada } \\
\text { promosi pruduk, } \\
\text { pembinaan, bantuan } \\
\text { modal kerja/usaha }\end{array}$ \\
\hline 3 & $\begin{array}{lr}\text { Jumlah } & \text { penduduk } \\
\text { yang } & \text { semakin } \\
\text { meningkat } & \text { sehingga } \\
\text { pasar semakin luas }\end{array}$ & 0,11 & 4 & 0,45 & $\begin{array}{lr}\text { Permintaan } & \text { pangsa } \\
\text { pasar selalu } & \\
\text { meningkat karna daya } \\
\text { tahan/mutu barang } \\
\text { pruduk meubel lebih } \\
\text { tinggi dibandingkan } \\
\text { hasil produksi } \\
\text { meubel/furniture yang } \\
\text { berbahan } \\
\text { campuran }\end{array}$ \\
\hline 4 & $\begin{array}{lll}\text { Upah tenaga } & \text { kerja } \\
\text { yang masih } & \text { relatif } \\
\text { murah } & & \\
\end{array}$ & 0,09 & 3 & 0,19 & $\begin{array}{lr}\text { Masih } & \text { kurangnya } \\
\text { lapangan } & \text { kerja dan } \\
\text { sesuai } & \text { dengan } \\
\text { kemampuan } & \text { skill dan } \\
\text { etos kerja } & \\
\end{array}$ \\
\hline 5 & $\begin{array}{lr}\text { Stabilitas } & \text { politik } \\
\text { memberikan } & \text { iklim } \\
\text { usaha yang } & \text { cukup } \\
\text { bagi industri meubel }\end{array}$ & 0,11 & 3 & 0,33 & $\begin{array}{lr}\text { Terjadi } & \text { permintaan } \\
\text { yang cukup } & \text { tinggi } \\
\text { karena hasil pruduk } \\
\text { meubel lokal dapat } \\
\text { digunakan sebagai } \\
\text { bantuan/hibah } & \text { kepada } \\
\text { masyarakat } & \text { yang } \\
\text { merupakan sarana } \\
\text { untuk mencapai tujuan } \\
\text { tertentu }\end{array}$ \\
\hline \multicolumn{6}{|c|}{ Ancaman } \\
\hline 1 & $\begin{array}{l}\text { Ketersediaan bahan } \\
\text { baku }\end{array}$ & 0,10 & -4 & $-0,41$ & $\begin{array}{l}\text { Menipisnya } \\
\text { ketersediaan bahan } \\
\text { baku dipengaruhi } \\
\text { akibat pembalakan liar } \\
\text { / ilegal loging }\end{array}$ \\
\hline 2 & Harga bahan baku & 0,1 & -3 & $-0,29$ & $\begin{array}{l}\text { Pemintaan masyarakat } \\
\text { yang tinggi sedangkan } \\
\text { bahan baku semakin } \\
\text { sulit didapat }\end{array}$ \\
\hline 3 & $\begin{array}{l}\text { Daya beli masyarakat } \\
\text { rendah }\end{array}$ & 0,09 & -3 & $-0,25$ & $\begin{array}{l}\text { Pengaruh kurs rupiah } \\
\text { dan } \\
\text { masyarakat menurun } \\
\text { sehingga memilih } \\
\text { barang subsitusi yang }\end{array}$ \\
\hline
\end{tabular}




\begin{tabular}{|c|l|c|c|c|l|}
\hline & & & & & $\begin{array}{l}\text { menyerupai dengan } \\
\text { berbahan baku plastik }\end{array}$ \\
\hline 4 & $\begin{array}{l}\text { Banyaknya beredar } \\
\text { produk sejenis dari } \\
\text { pesaing }\end{array}$ & 0,09 & -3 & $-0,28$ & $\begin{array}{l}\text { Meningkatnya nilai } \\
\text { seni bentuk/model, } \\
\text { efesiensi bahan baku } \\
\text { dan nilai ekonomis } \\
\text { yang tinggi }\end{array}$ \\
\hline 5 & $\begin{array}{l}\text { Tarif dasar listrik } \\
\text { (TDL) dan bahan } \\
\text { bakar minyak } \\
\text { semakin mahal }\end{array}$ & 0,07 & -2 & $-0,13$ & $\begin{array}{l}\text { Dapat mempengaruhi } \\
\text { biaya produksi yang } \\
\text { tinggi dalam } \\
\text { penggunaan peralatan }\end{array}$ \\
\hline
\end{tabular}

Sumber: Hasil Penelitian (2015)

Pada tabel 10 dapat dilihat bahwa jumlah skor untuk faktor strategis eksternal (peluang dan ancaman) untuk untuk UMKM meubel di Kota Bengkulu adalah sebesar 0,56. Pada Tabel 10 di atas juga diperoleh peluang dalam Strategi Pengembangan UMKM Meubel di Kota Bengkulu adalah sebagai berikut:

a. Adanya dukungan pemerintah dalam mengembangkan umkm $(0,49)$

b. Meningkatnya income per kapita $(0,47)$

c. Jumlah penduduk yang semakin meningkat sehingga pasar semakin luas $(0,45)$

d. Stabilitas politik memberikan iklim usaha yang cukup bagi industri meubel $(0,33)$

e. Upah tenaga kerja yang masih relatif murah $(0,19)$

Sedangkan ancaman dalam Strategi Pengembangan UMKM Meubel di Kota Bengkulu adalah sebagai berikut:

a. ketersediaan bahan baku s $(-0,41)$

b. harga bahan baku $(-0,29)$

c. banyaknya beredar produk sejenis dari pesaing $(-0,28)$

d. daya beli masyarakat rendah $(-0,25)$

e. tarif dasar listrik (TDL) dan bahan bakar minyak semakin mahal $(-0,13)$

Berdasarkan Tabel 9 dapat dilihat bahwa jumlah skor faktor strategis internal sebesar 0,41 dan pada tabel 10 dapat dilihat bahwa jumlah skor faktor strategi eksternal sebesar 0,56 maka hasil analisis SWOT yang didapatkan, jika dimasukkan ke dalam grafik maka akan seperti gambar 3 berikut ini. 


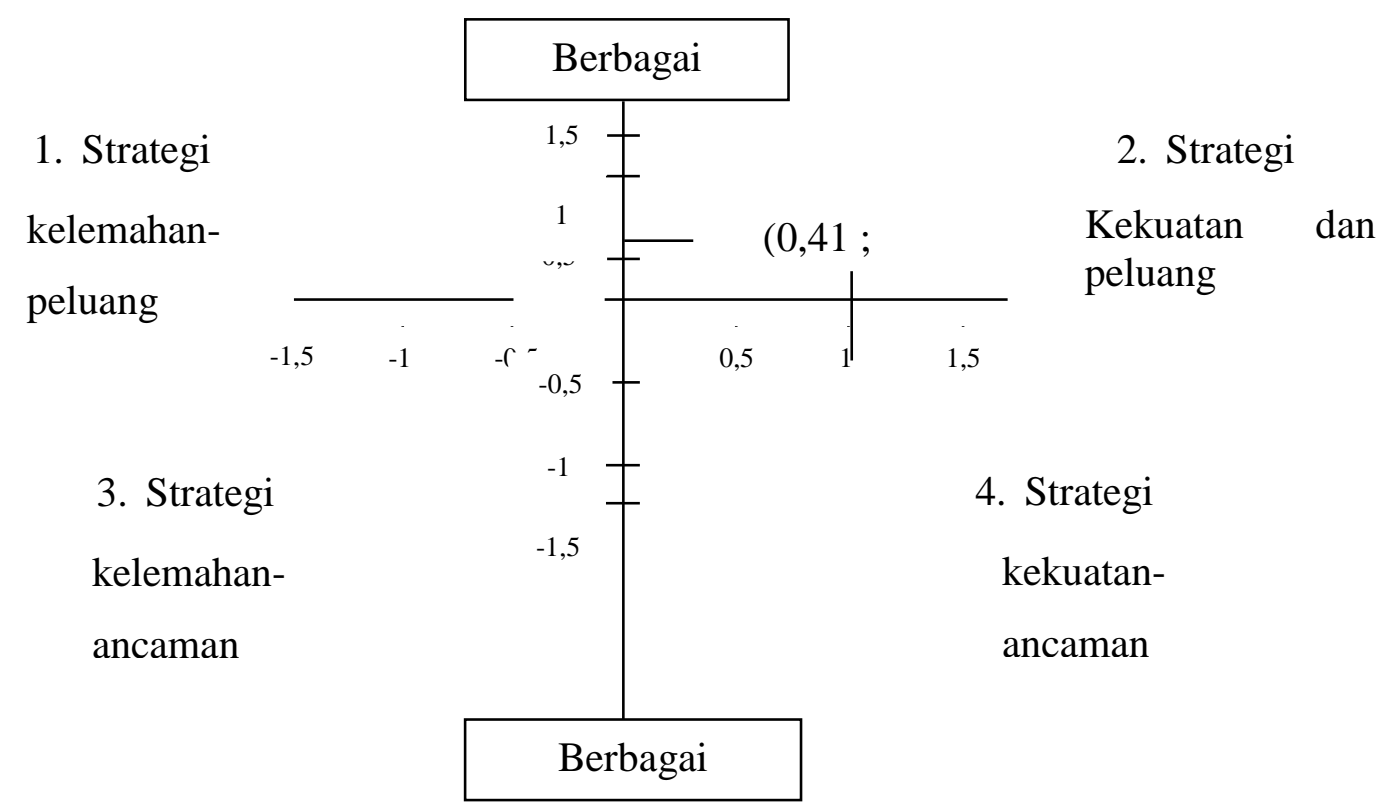

Gambar 3. Hasil Analisis SWOT(data diolah, 2015)

Dari peta SWOT tersebut di atas dapat dilihat bahwa posisi SWOT berada pada kuadran 1 yang merupakan situasi yang sangat menguntungkan, UMKM meubel di Kota Bengkulu memiliki peluang dan kekuatan sehingga dapat memanfaatkan peluang yang ada. Strategi yang harus diterapkan dalam kondisi ini adalah mendukung kebijakan pertumbuhan yang agresif atau growth oriented strategy (Strategi SO atau strategi kekuatan/ strenghts - peluang/ opportunities), dan memiliki peluang yang besar untuk berkembang menjadi usaha atau industri yang lebih besar di Kota Bengkulu. Alat yang dipakai untuk menyusun faktorfaktor strategis UMKM meubel di Kota Bengkulu adalah matrik SWOT. Matrik ini dapat menggambarkan secara jelas bagaimana peluang dan ancaman eksternal yang dihadapi UMKM meubel di Kota Bengkulu dapat disesuaikan dengan kekuatan dan kelemahan yang dimilikinya. Analisis Matrik SWOT berikut ini dapat menghasilkan empat set kemungkinan alternatif strategis (Rangkuti, 2006):

Tabel 11. Matrik Analisis SWOT Untuk Merumuskan Alternatif Strategi

\begin{tabular}{|c|c|c|}
\hline Faktor internal & $\begin{array}{l}\text { Kekuatan (strenghts) } \\
\text { 1. Produk bernilai ekonomis tinggi } \\
\text { 2. Kualitas produk } \\
\text { 3. Sistem kekeluargaan } \\
\text { 4. Menjalin kerjasama dengan } \\
\text { pemerintah } \\
\text { 5. Lokasi usaha }\end{array}$ & $\begin{array}{l}\text { Kelemahan (weaknesses) } \\
\text { 1. Teknologi } \\
\text { 2. Ketersedian SDM } \\
\text { 3. Kapasitas produksi } \\
\text { 4. Modal usaha } \\
\text { 5. Promosi produk }\end{array}$ \\
\hline \multicolumn{3}{|l|}{ Faktor eksternal } \\
\hline $\begin{array}{l}\text { Peluang } \\
\text { (opportunities) } \\
\text { 1. Peningkatan } \\
\text { income per kapita }\end{array}$ & $\begin{array}{l}\text { Strategi SO } \\
\text { 1. Memperluas pangsa pasar (S1, } \\
\text { S2, S4, O1, O2, O3, O5) } \\
\text { 2. Mempertahankan dan }\end{array}$ & $\begin{array}{l}\text { Strategi WO } \\
\text { 1. Memperbaiki sistem } \\
\text { manajemen }(\mathrm{W} 1, \mathrm{~W} 2 \text {, } \\
\text { W4, O1, O3) } \\
\end{array}$ \\
\hline
\end{tabular}




\begin{tabular}{|c|c|c|}
\hline $\begin{array}{l}\text { 2. Dukungan } \\
\text { pemerintah } \\
\text { 3. Jumlah penduduk } \\
\text { 4. Upah tenaga kerja } \\
\text { 5. Stabilitas politik } \\
\end{array}$ & $\begin{array}{l}\text { meningkatkan kualitas layanan } \\
\text { kepada pelanggan (S2, S5, O1, } \\
\text { O3) } \\
\text { 3. Meningkatkan kualitas produk } \\
\text { (S1, S2, S3, 04) }\end{array}$ & $\begin{array}{l}\text { 2. Memperkuat modal } \\
\text { melalui kerjasama dengan } \\
\text { instansi pemerintahan } \\
(\mathrm{W} 3, \mathrm{~W} 5, \mathrm{O} 2, \mathrm{O} 5)\end{array}$ \\
\hline $\begin{array}{l}\text { Ancaman (threats) } \\
\text { 1. Ketersediaan bahan } \\
\text { baku } \\
\text { 2. Harga bahan baku } \\
\text { 3. Daya beli } \\
\text { masyarakat } \\
\text { 4. Produk sejenis } \\
\text { 5. Tarif dasar listrik } \\
\text { dan bahan bakar }\end{array}$ & $\begin{array}{l}\text { Strategi ST } \\
\text { 1. Menetapkan strategi harga pasar } \\
\text { untuk menghadapi persaingan } \\
\text { (S1, S2, T2, T3, T5) } \\
\text { 2. Meningkatkan promosi (S1, S2, } \\
\text { T3, T4) } \\
\text { 3. Penghematan biaya produksi } \\
\text { (S1, T1, T2, T3, T4, T5) }\end{array}$ & $\begin{array}{l}\text { Strategi WT } \\
\text { 1. Meningkatkan teknologi } \\
\text { (W1, W5, T1) } \\
\text { 2. Meningkatkan kreatifitas } \\
\text { SDM (W2, W3, T3) } \\
\text { 3. Bantuan pendanaan yang } \\
\text { mudah dan bunga rendah } \\
\text { dari pemerintah (W4, T2, } \\
\text { T5) }\end{array}$ \\
\hline
\end{tabular}

Sumber: data diolah (2015)

Berdasarkan tabel 11 matrik analisis SWOT tersebut di atas, maka strategi yang digunakan oleh UMKM meubel di Kota Bengkulu yaitu strategi SO atau strategi kekuatan-peluang menggunakan seluruh kekuatan internal UMKM meubel di Kota Bengkulu untuk merebut dan memanfaatkan peluang sebesar-besarnya. Solusi strategi tersebut yaitu:

\section{Memperluas pangsa pasar}

Seiring kemajuan perekonomian masyarakat dan pertumbuhan jumlah penduduk, maka perlu dilakukan perluasan pangsa pasar untuk menyentuh berbagai lapisan masyarakat, baik tingkat atas, menengah, maupun bawah.Perluasan pangsa pasar juga dilakukan ke luar daerah Bengkulu, supaya mendapatkan konsumen yang lebih banyak.

Untuk memperluas pangsa pasar diperlukan perencanaan startegis lebih matang dan bagaimana manajemen puncak menentukan visi, misi, falsafah dan strategi perusahaan guna mencapai tujuan perusahaan dalam jangka panjang (Umar, 2008). Selain perencanaan startegis yang matang, diperlukan juga kerjasama antar UMKM meubel di Kota Bengkulu dan Pemerintah atau pihak yang terkait untuk mendapatkan solusi dan perencanaan lebih jitu dalam pengembangan UMKM meubel di Kota Bengkulu, seperti kemudahan dalam mendapatkan modal usaha, bantuan teknologi, dan pelatihan.

2. Mempertahankan dan meningkatkan kualitas layanan kepada pelanggan

Pelanggan atau konsumen adalah nyawa bagi UMKM meubel di Kota Bengkulu.Oleh karena itu, kualitas pelayanan bagi pelanggan harus ditingkatkan.Baik itu sebelum transaksi, ketika terjadi transaksi maupun layanan purna jual produk-produk meubel itu sendiri. Mempertahankan dan meningkatkan kualitas layanan kepada pelanggan merupakan salah satu strategi menghadapi persaingan dengan UMKM lain di bidang yang sama.

Rahayu (2008), menjelaskan bahwa suatu organisasi akan memiliki keunggulan bersaing atau memiliki potensi untuk bersaing apabila dapat menciptakan dan menawarkan nilai pelanggan yang lebih atau kinerjanya lebih baik dibandingkan dengan organisasi lainnya. 


\section{Meningkatkan kualitas produk}

Kualitas produk meubel yang sudah ada harus dipertahankan, jika perlu ditingkatkan lagi.Hal ini dilakukan supaya produk-produk meubel yang dihasilkan bisa bertahan dengan persaingan pasar meubel yang ada di Kota Bengkulu dan juga kualitasnya tidak kalah dengan gempuran produk-produk meubel yang masuk dari luar Kota Bengkulu.

\section{Pembahasan}

Selama ini perhatian terhadap pengembangan UMKM meubel oleh pemerintah sebenarnya telah banyak dilakukan. Banyak program dan kegiatan yang berlabel pengembangan UMKM meubel telah, sedang dan akan dilaksanakan. Program-program tersebut yang pada umumnya menggunakan pendekatan pemberdayaan masyarakat.Namun sebagian besar program-program tersebut belum secara substansial mengembangkan UMKM meubel.Titik berat program lebih banyak diarahkan pada pemberdayaan masyarakat dan masih bersifat proyek, serta bersifat top down dari pemerintah pusat.Pada umumnya program-program tersebut tidak berkelanjutan (sustainable) setelah masa proyek berakhir.

Dalam rangka menyusun kebijakan dan strategi dalam pengembangan UMKM meubel terdapat tiga kategori permasalahan, pertama sebagai permasalahan dasar (basic problem) pada UMKM meubel, yang mencakup berbagai aspek antara lain aspek pemasaran, aspek SDM, aspek teknologi, aspek keuangan, aspek legalitas dan aspek permodalan/pendanaan, kedua, permasalahan antara (intermediate problem) dapat berupa kurangnya informasi maupun data-data yang akurat dan terkini mengenai peluang pasar baik dalam maupun luar negeri, kesulitan UMKM meubel dalam mengaskses bank, kurangnya sumberdaya manusia yang cakap atau memadai dalam hal enterpreneurship, manajemen, tehnik produksi, pengembangan produk, yang masih belum optimal. Dan yang ketiga permasalahan lebih lanjut (advanced problem) tertutama terkait dengan pengembangan ekspor, diantaranya berupa permasalahan pengenalan pasar dan penetrasi pasar untuk promosi ekspor yang belum optimal, kurangnya pemahaman terhadap desain produk yang sesuai dengan karakter pasar, permasalahan hukum yang menyangkut hak paten, kontrak penjualan serta peraturan yang berlaku di negara tujuan ekspor.

Sebaiknya kebijakan UMKM meubel difokuskan pada peningkatan kemampuan teknologi dan sumberdaya manusia di UMKM meubel, karena kedua faktor tersebut sangat menentukan keberhasilan UMKM meubel dalam bersaing dengan usaha besar di pasar domestik maupun produk-produk UMKM meubel dari negara lain. Jadi yang menjadi tolak ukur keberhasilan kebijakan UMKM meubel ini ádalah bukan jumlah UMKM meubel yang meningkat setiap tahun atau jumlah UMKM meubel yang mendapat kredit bank yang meningkat setiap tahun, tetapi jumlah UMKM meubel yang dalam periode tertentu berhasil menembus pasar ekspor, atau meningkatkan pasar ekspornya, atau berhasil melakukan transformasi dari produk sederhana atau yang stándar ke 
produk rekayasa yang lebih komplek, atau berhasil membentuk kemitraan dalam proses produksi dengan perusahaan asing. Untuk itu banyak hal yang perlu dilakukan oleh pemerintah dan swasta dalam suatu koordinasi yang baik.

\section{Kesimpulan}

Berdasarkan hasil analisis pada bab sebelumnya maka kesimpulan dalam penelitian ini adalah sebagai berikut.

1. Faktor strategi pengembangan yang digunakan oleh UMKM meubel di Kota Bengkulu, adalah:

a. Faktor internal

i. Kekuatan (strenghts):

- Produk bernilai ekonomis tinggi

- Kualitas produk

- Sistem kekeluargaan

- Menjalin kerjasama dengan pemerintah

- Lokasi usaha strategis

ii. Kelemahan (weaknesses):

- Teknologi

- Ketersedian SDM

- Kapasitas produksi

- Modal usaha

- Promosi produk

b. Faktor eksternal

i. Peluang (opportunities):

- Peningkatan income per kapita

- Dukungan pemerintah

- Jumlah penduduk

- Upah tenaga kerja

- Stabilitas politik

ii. Ancaman (threats):

- Ketersediaan bahan baku

- Harga bahan baku

- Daya beli masyarakat

- Produk sejenis

- Tarif dasar listrik dan bahan bakar 
2. Strategi yang harus diterapkan dalam kondisi ini adalah strategi SO (Strengths-Opportunies) atau strategi kekuatan-peluang. Strategi tersebut adalah:

i. Memperluas pangsa pasar

ii. Mempertahankan dan meningkatkan kualitas layanan kepada pelanggan

iii. Meningkatkan kualitas produk

\section{Saran}

Berdasarkan hasil penelitian dan analisis data serta kesimpulan di atas maka dapat diberikan beberapa saran yakni sebagai berikut:

1. Setelah mengetahui faktor-faktor internal (kekuatan dan kelemahan) dan faktor-faktor eksternal (peluang dan ancaman) yang dimiliki oleh UMKM meubel di Kota Bengkulu, maka UMKM meubel dapat membuat strategi dan peningkatan daya saing yang kuat berdasarkan kekuatan dan kelemahan yang dimiliki. Untuk menghadapi daya saing yang mengancam saat ini dan di masa yang akan datang perlu adanya kerjasama antara UMKM meubel di Kota Bengkulu dengan pemerintah daerah atau pihak terkait dalam pengembangan dan peningkatan kualitas UMKM meubel di Kota Bengkulu , seperti:

a. Memperluas pangsa pasar;

UMKM meubel bekerjasama dengan pemerintah melakukan promosi ke luar daerah dengan mengadakan pameran atau ikut pameran meubel bertarap nasional maupun internasional.

Promosi juga dapat dilakukan dengan membuat web internet khusus UMKM meubel Kota Bengkulu, sehingga promosi bisa menjangkau ke seluruh negara di dunia ini.

b. Mempertahankan dan meningkatkan kualitas layanan kepada pelanggan;

Membuat layanan purna jual, seperti menerima keluhan, perbaikan meubel yang telah terjual ke konsumen jika terjadi kerusakan; memberikan garansi produk meubel.

c. Meningkatkan kualitas produk;

UMKM meubel bekerjasama dengan pemerintah untuk meningkatkan kualitas produk, seperti pemerintah memberikan bantuan teknologi komputerisasi kepada UMKM meubel, sehingga bisa mempercepat produksi dan memperbanyak kuantitas produksi.

2. Bagi peneliti selanjutnya agar menjadikan hasil penelitian ini sebagai referensi penelitian selanjutnya.

\section{Daftar Pustaka}

Bantacut.dkk. 2001. Pengembangan Ekonomi Berbasis Usaha Kecil dan Menengah dalam Kemitraan dan Pengembangan Ekonomi Lokal.Yayasan Mitra Pembangunan Desa-Kota BussinessInovation Center of Indonesia, Jakarta.

David, F. R. 2004. Manajemen Strategi: Konsep-konsep. Edisi Sembilan. Indeks. Jakarta.

Dinas Koperasi dan PPKM Kota Bengkulu, 2013.Laporan Hasil Pendapatan Usaha Mikro Dan Menengah Tahun Anggaran 2013 Di Kota Bengkulu.Dinas Koperasi dan PPKM, Bengkulu.

Kinnear, Thomas C. and James R. Taylor. 1995. Marketing Research: An Applied Approach.Fifth Edition.McGraw Hill Text.

Nawawi, Hadari. 1987. Metode Penelitian Bidang Sosial. Universitas Gajah Mada. Pers.Yogyakarta 
Prawiro, Radius.1998, Pergulatan Indonesia Membangun Ekonomi. Pragmatisme Dalam Aksi.PT ElexMedia Komputindo . Jakarta.

Rangkuti, Freddy.2006. Analisis SWOT Teknik Membedah Kasus Bisnis.PT Gramedia Pustaka Utama. Jakarta.

Sevilla.dkk. 2000. Pengantar Metode Penelitian. Universitas Indonesia. Jakarta.

Undang-Undang Republik Indonesia Nomor 20 Tahun 2008. Tentang Usaha Mikro, Kecil, dan Menengah.

Umar, H. 2008. Manajemen Strategi in Action. PT. Gramedia Pustaka Utama, Jakarta.

https://www.bps.go.id/pressrelease/2012/11/05/65/pada-agustus-2012--tingkat-pengangguran-terbuka--tpt-sebesar-6-14-

persen.html\#: :text=Tingkat\%20Pengangguran\%20Terbuka\%20(TPT)\%20di,2011\%20sebesar\%206\%2C56 \%20persen.

http://www.depkop.go.id/uploads/tx_rtgfiles/Rencana_Kerja_Pemerintah_Tahun_2014.pd 